\title{
Diabetes mellitus and primary hyperparathyroidism
}

\author{
C. H. WALSh \\ M.D., M.R.C.P.
}

\author{
N. G. SOLER \\ M.D., Ph.D., M.R.C.P.
}

\author{
J. M. Malins \\ M.D., F.R.C.P.
}

The General Hospital, Birmingham B4 6NH

\begin{abstract}
Summary
Eight patients suffering from primary hyperparathyroidism and diabetes mellitus are reported. All of the patients are female. The clinical problems resulting from the co-existence of these two endocrine disorders and the similarity of their symptoms are discussed. The experience from a large diabetic clinic population suggests that the association of hyperparathyroidism with diabetes merits further investigation.
\end{abstract}

\section{Introduction}

The prevalence of diabetes mellitus in the population is at least $1-1.5 \%$ and is probably considerably higher in the older age group (Malins, 1968). Thus, it is not surprising that various other endocrine disorders such as hypothyroidism and hypoadrenalism may occur in association with diabetes mellitus (Hecht and Gershberg, 1968; Soloman et al., 1965). The co-existence of diabetes mellitus and primary hyperparathyroidism has, however, only rarely been reported and in nearly all instances the evidence has suggested that the diabetes was secondary to pancreatitis (Jackson, 1958; Gross, 1958; Kipnis, 1969).

We report here the co-existence of primary hyperparathyroidism and diabetes mellitus in eight patients.

\section{Patients and investigations}

Between 1961 and 1973, primary hyperparathyroidism was diagnosed in eight patients attending the diabetic clinic. In six cases a diagnosis was confirmed histologically (Table 1) and in the remaining two the diagnosis was based on the finding of persistent hypercalcaemia, elevated parathormone levels, normal renal function and exclusion of other causes of hypercalcaemia. Hyperparathyroidism was suspected in three patients following the discovery of hypercalcaemia on routine biochemical screening. In the remaining patients the presenting symptoms were muscular and skeletal pain (two cases), renal

Reprints requests to: Dr C. H. Walsh, The General Hospital, Steelhouse Lane, Birmingham B4 6NH. calculi (one case), polyuria, polydipsia and fatigue (one case) and peptic ulceration with haematemesis (one case). In all cases a diagnosis of diabetes was based on the presence of a blood sugar of over $250 \mathrm{mg} / 100 \mathrm{ml}$. Details of the patients are given in Tables 1 and 2. The case histories of two patients are described briefly. They are Case E.C. and Case K.H.

\section{Case E.C.}

In 1970 she attended an orthopaedic clinic with pain in the shoulders and back. She was noted to have glycosuria and was referred to the diabetic clinic where she admitted to having noticed thirst, polyuria, weight loss and, in particular, fatigue for several months. Her mother had suffered from diabetes. Following a diagnosis of diabetes she was treated with glibenclamide. Over the next 6 months she continued to lose weight. In addition, her thirst, polyuria and fatigue persisted despite good diabetic control. Further investigation revealed the presence of hypercalcaemia and a tentative diagnosis of primary hyperparaţhyroidism was made. Skeletal survey at this time showed reduced bone density. Abdominal X-ray showed flecks of calcification in the left upper quadrant. Her hyperparathyroidism was treated surgically and a single hyperplastic gland was removed. The other parathyroid glands were not located. Her serum calcium fell to normal temporarily and her symptoms disappeared. A year later her serum calcium rose to $10.9 \mathrm{mg} / 100 \mathrm{ml}$. Her symptoms have not returned so far and her serum calcium ranges between 10.8 and $11.5 \mathrm{mg} / 100 \mathrm{ml}$.

\section{Case K.H.}

This patient was admitted as an emergency following a haematemesis and melaena. Gastroscopy showed an actively bleeding lesion just below the cardio-oesophageal junction. In addition, an inactive duodenal ulcer was seen. On admission, heavy glycosuria was noted and a blood sugar was $389 \mathrm{mg} /$ $100 \mathrm{ml}$. She denied any symptoms of diabetes. She was treated with insulin. Following admission her 
TABLE 1. Clinical details of the eight patients. The age given is that at the time diabetes was diagnosed

\begin{tabular}{|c|c|c|c|c|c|c|}
\hline Case & Age & Sex & $\begin{array}{l}\text { Diabetes } \\
\text { diagnosed }\end{array}$ & $\begin{array}{l}\text { Hyperpara- } \\
\text { thyroidism } \\
\text { diagnosed }\end{array}$ & $\begin{array}{l}\text { Treatment } \\
\text { for diabetes }\end{array}$ & Co-existing disorder \\
\hline N.C. & 56 & $\mathbf{F}$ & 1961 & 1972 & Chlorpropamide & $\begin{array}{l}\text { Hypothyroidism } \\
\text { Hypertension }\end{array}$ \\
\hline M.M. & 50 & $\mathbf{F}$ & 1962 & 1972 & Insulin & - \\
\hline J.D. & 60 & $\mathbf{F}$ & 1964 & 1971 & Chlorpropamide & Renal calculi \\
\hline E.A. & 60 & $\mathbf{F}$ & June 1968 & August 1968 & Chlorpropamide & Cholelithiasis \\
\hline E.C. & 65 & $\mathbf{F}$ & January 1970 & January 1970 & Glibenclamide & Cholelithiasis \\
\hline S.M. & 62 & $\mathbf{F}$ & September 1972 & February 1973 & Chlorpropamide & $\begin{array}{l}\text { Hypothyroidism } \\
\text { Pernicious anaemia } \\
\text { Cholelithiasis } \\
\text { Hypertension }\end{array}$ \\
\hline $\begin{array}{l}\text { G.E. } \\
\text { K.H. }\end{array}$ & $\begin{array}{l}74 \\
74\end{array}$ & $\begin{array}{l}\mathbf{F} \\
F\end{array}$ & $\begin{array}{c}\text { January } 1973 \\
\text { December } 1973\end{array}$ & $\begin{array}{c}\text { January } 1973 \\
\text { December } 1973\end{array}$ & $\begin{array}{c}\text { Glymidine } \\
\text { Insulin }\end{array}$ & $\begin{array}{l}\text { Peptic ulcer } \\
\text { Nodular goitre }\end{array}$ \\
\hline
\end{tabular}

TABLE 2. Laboratory and radiological investigations in the eight patients. The figures in parenthesis indicate the normal range for our laboratory

\begin{tabular}{|c|c|c|c|c|c|c|c|c|}
\hline Case & $\begin{array}{c}\text { Serum } \\
\text { calcium } \\
(8 \cdot 6-10 \cdot 4 \\
\mathrm{mg} / 100 \mathrm{ml})\end{array}$ & $\begin{array}{c}\text { Serum } \\
\text { phosphorus } \\
(2 \cdot 5-4 \cdot 5 \\
\mathrm{mg} / 100 \mathrm{ml})\end{array}$ & $\begin{array}{c}\text { Alkaline } \\
\text { phosphatase } \\
\text { (4-14 K.A. } \\
\text { units) }\end{array}$ & $\begin{array}{c}\text { Serum } \\
\text { albumin } \\
(3 \cdot 6-4 \cdot 8 \\
\mathrm{g} / 100 \mathrm{ml})\end{array}$ & $\begin{array}{c}\text { Serum } \\
\text { urea } \\
(15-50 \\
\mathrm{mg} / 100 \mathrm{ml})\end{array}$ & $\begin{array}{l}\text { Radiological } \\
\text { survey }\end{array}$ & $\begin{array}{c}\underset{\text { Serum }}{\text { PTH } \dagger} \\
(\mathrm{ng} / 100 \mathrm{ml})\end{array}$ & $\begin{array}{l}\text { Para- } \\
\text { thyroid } \\
\text { histology }\end{array}$ \\
\hline N.C. & $11 \cdot 6$ & $2 \cdot 5$ & 10 & $4 \cdot 0$ & 34 & $\begin{array}{l}\text { Chondro- } \\
\text { calcinosis of } \\
\text { wrists }\end{array}$ & $2 \cdot 1$ & - \\
\hline $\begin{array}{l}\text { M.M. } \\
\text { J.D. }\end{array}$ & $\begin{array}{l}11 \cdot 7 \\
11 \cdot 1\end{array}$ & $\begin{array}{l}2 \cdot 8 \\
2 \cdot 9\end{array}$ & $\begin{array}{l}11 \\
15\end{array}$ & $\begin{array}{l}4 \cdot 7 \\
4 \cdot 1\end{array}$ & $\begin{array}{l}27 \\
66\end{array}$ & $\begin{array}{c}\downarrow \text { Bone density } \\
\text { Renal calculi }\end{array}$ & $\frac{1 \cdot 12}{-}$ & $\begin{array}{l}\text { Single } \\
\text { adenoma }\end{array}$ \\
\hline C.A. & $12 \cdot 7$ & $1 \cdot 5$ & 26 & $4 \cdot 3$ & 36 & $\downarrow$ Bone density & - & $\begin{array}{l}\text { Single } \\
\text { adenoma }\end{array}$ \\
\hline E.C. & $11 \cdot 1$ & $2 \cdot 8$ & 14 & $4 \cdot 0$ & 32 & $\begin{array}{l}\text { Pancreatic } \\
\text { calcification. } \\
\text { Sub-periosteal } \\
\text { erosions of } \\
\text { phalanges }\end{array}$ & 一 & $\begin{array}{l}\text { Hyper- } \\
\text { plasia }\end{array}$ \\
\hline S.M. & $11 \cdot 8$ & $2 \cdot 7$ & 16 & $4 \cdot 2$ & 42 & $\begin{array}{l}\text { Chondro- } \\
\text { calcinosis } \\
\text { of wrists }\end{array}$ & $3 \cdot 8$ & $\begin{array}{l}\text { Single } \\
\text { adenoma }\end{array}$ \\
\hline G.E. & $13 \cdot 8$ & - & 44 & $4 \cdot 3$ & $0 \cdot 8^{*}$ & No abnormality & - & $\begin{array}{l}\text { Single } \\
\text { adenoma }\end{array}$ \\
\hline K.H. & $12 \cdot 3$ & $2 \cdot 5$ & 12 & $3 \cdot 4$ & 34 & No abnormality & $2 \cdot 2$ & $\begin{array}{l}\text { Single } \\
\text { adenoma }\end{array}$ \\
\hline
\end{tabular}

* Serum creatinine.

† Serum parathyroid hormone was kindly measured by Dr J. L. H. O'Riordan by a radioimmunoassay. The upper limit of normal is $0.9 \mathrm{ng} / \mathrm{ml}$.

serum calcium was $11.0 \mathrm{mg} / 100 \mathrm{ml}$. Further investigation suggested a diagnosis of primary hyperparathyroidism. A skeletal survey showed reduced bone density and X-ray of the abdomen was normal. She underwent operation and a single parathyroid adenoma was removed. Subsequently, her serum calcium has remained normal. A week after the operation she developed repeated severe hypoglycaemic episodes and her insulin dose, which before operation was Lente 56 units, had to be reduced to Lente 16 units. Her diabetes has remained well controlled on this dose.

\section{Discussion}

It is well recognized that thirst and polyuria, which are two of the commonest symptoms of diabetes, are also prominent symptoms of hyperparathyroidism. It is less widely appreciated, however, that fatigue and weight loss, also prominent features of diabetes, may be major symptoms of hyperparathyroidism (Aurbach et al., 1973). Thus, if the two endocrine disorders co-exist, the symptoms of one may mask those of the other. Case E.C. is a typical example. In this patient it was only when thirst, fatigue and weight loss persisted for several 
months despite adequate control of the diabetes that hyperparathyroidism was suspected. In addition, it has been our experience that because many of the symptoms are common to both disorders, patients with primary hyperparathyroidism alone may be mistakenly referred to a diabetic clinic.

It is not certain whether there is an aetiological link between diabetes mellitus and hyperparathyroidism. In five of our patients the interval between the diagnosis of both conditions was 6 months or less and in the remaining three cases diabetes was diagnosed several years before hyperparathyroidism. Since it is recognized that both diabetes and hyperparathyroidism may exist for many years before being diagnosed, we cannot be certain which disorder developed first. If it is postulated that hyperparathyroidism is the primary disorder then there are a number of ways, at least in theory, in which this might be associated with the development of diabetes. Kim et al. (1971) observed that patients with primary hyperparathyroidism have endogenous insulin resistance which may be improved by surgical correction of the parathyroid disorder. It is interesting that one of our patients (Case K.H.) developed repeated severe hypoglycaemic reactions some days after removal of the parathyroid adenoma and a considerable reduction of insulin dosage was necessary. The rare, though well documented, association between hyperparathyroidism and pancreatitis (with or without calcification) (Mixter, Keynes and Cope, 1962) suggests another way in which hyperparathyroidism might be linked aetiologically with diabetes. Many authors feel that it is the hyperparathyroidism which occurs first and leads to the development of the pancreatic lesion. It seems quite possible that in some of these cases diabetes might utilmately result. However, only one of our patients (Case E.C.) had radiological evidence of pancreatic calcification. In addition, the one patient who underwent autopsy was found to have no evidence of pancreatic calcification or pancreatitis. Although exocrine pancreatic function was not investigated in our patients, none gave a history suggestive of pancreatitis. In addition, it has been pointed out that pancreatitis is unlikely to cause diabetes unless there has been extensive destruction of the organ (Malins, 1968). Finally, the elevated plasma glucagon levels sometimes associated with hyperparathyroidism might result in diabetes (Paloyan, 1967). On the other hand, it is difficult to see how diabetes as the primary disorder could predispose to the development of hyperparathyroidism, although on the basis of current experimental work (Paloyan, 1967; Cushard et al., 1971) it is conceivable that the hyperglucagonaemia associated with diabetes might result in reactive parathyroid hyperfunction. For the moment, however, this is entirely speculative.
There is little evidence that patients with primary hyperparathyroidism have an unexpectedly high incidence of diabetes. Dent (1962) noted only one case of diabetes in a series of eighty patients with hyperparathyroidism. Numerous other reports of large series of patients with primary hyperparathyroidism make no mention of the occurrence of diabetes, although whether this was specifically looked for is not stated (Aurbach et al., 1973; Purnell et al., 1971; Keating, 1961). Parathormone has been shown to increase renal tubular glucose resorption (Halver, $^{2}$ $1967)$ and if urine testing is relied upon as a screening procedure for diabetes in these patients mild cases might be overlooked. There is no information on the frequency with which primary hyperparathyroidism occurs in patients with diabetes. Between 1961 and 1973, 9900 diabetics were seen at our clinic. This suggests that the prevalence of hyperparathyroidism among diabetics is approximately 1 in 1200 . The prevalence of hyperparathyroidism in patients attending hospital has been estimated at approximately 1 in 1000 (Boonstra and Jackson, 1971) and 1 in 2000 (Haff, Blade and Ballinger, 1970). However, only a minority of diabetics attending our clinic have had serum calcium estimations and so our figure is undoubtedly an underestimate. Primary hyperparathyroidism is more common in females than in males and in a recent large series (Purnell et al., 1971) the female: male ratio was approximately $2: 1$. Although there is a slight preponderance of females of the age group in question attending our diabetic clinic, it is perhaps surprising that primary hyperparathyroidism has not been diagnosed in a male diabetic during the period of this study.

Hyperparathyroidism has been reported in association with various other endocrine disturbances including thyrotoxicosis (Frame and Durham, 1959), Cushing's syndrome (Raker, Henneman and Graf, 1962), acromegaly (Dent, 1962) and the ZollingerEllison syndrome (Summerskill et al., 1961). In addition, it is the principle endocrine disorder in the polyglandular syndrome (Ballard, Frame and Hartsock, 1964). Two of our patients not only had diabetes mellitus and primary hyperparathyroidism, but also hypothyroidism. This triad of endocrine disturbances has not previously been reported.

Our observations underline some of the problems which may be encountered when diabetes mellitus and primary hyperparathyroidism co-exist. Although there are theoretical reasons for suspecting an aetiological relationship between these two endocrine disorders, it remains to be determined whether their co-existence is more than coincidental.

\section{References \\ Aurbach, G.D., Mallette, L.E., Patren, B.M., Heath, D.A., Doppman, J.L. \& BilezIrian, J.P. (1973) Hyper-}


parathyroidism : recent studies. Annals of Internal Medicine, 79, 566.

Ballard, H.S., Frame, B. \& Hartsock, R.J. (1964) Familial multiple endocrine adenoma-peptic ulcer complex. Medicine, 43, 481.

Boonstra, C.E. \& JACKson, C.E. (1971) Serum calcium survey for hyperparathyroidism: results in 50,000 clinic patients. Journal of Clinical Pathology, 55, 523.

Cushard, W. JR, Bercovitz, M., Canterbury, J.M. \& ReIss, E. (1971) Hormonal stimulation of parathyroid hormone secretion in man. Journal of Clinical Investigation, 50, 23A.

DENT, C.E. (1962) Some problems of hyperparathyroidism. British Medical Journal, ii, 1419.

Frame, B. \& Durham, R.H. (1959) Simultaneous hyperthyroidism and hyperparathyroidism. American Journal of Medicine, 27, 824.

Gross, J.B. (1958) Some recent developments pertaining to pancreatitis. Annals of Internal Medicine, 49, 796.

HAFF, R.C., BLACK, W.C. \& BALlinger, W.F. (1970) Primary hyperparathyroidism: changing clinical, surgical and pathologic aspects. Annals of Surgery, 171, 85.

HALVER, B. (1967) Glucose metabolism in parathyroid disease. Acta medica scandinavica, 181, 209.

Hecht, A. \& Gershberg, H. (1968) Diabetes mellitus and primary hypothyroidism. Metabolism, 17, 108.

JACKSON, C.E. (1958) Hereditary hyperparathyroidism associated with recurrent pancreatitis. Annals of Internal Medicine, 49, 829.

KeatiNG, R.F. (1961) Diagnosis of primary hyperparathyroidism. Clinical and laboratory aspects. Journal of the American Medical Association, 178, 547.
Kim, H., Kalhoff, R.K., Costrini, N.U., Cerletty, J.M. \& JACOBSON, M. (1971) Plasma insulin disturbances in primary hyperparathyroidism. Journal of Clinical Investigation, 50, 2596.

KIPNIS, D.M. (1969) Clinicopathologic Conference: Multiple endocrine adenomatosis. American Journal of Medicine, 47, 608.

MaLINS, J.M. (1968) In: Clinical Diabetes Mellitus. Eyre and Spottiswoode, London.

Mixter, C.G. JR, Keynes, W.M. \& Cope, O. (1962) Further experience with pancreatitis as a diagnostic clue to hyperparathyroidism. New England Journal of Medicine, 266, 265.

Paloyan, E. (1967) Recent developments in the early diagnosis of hyperparathyroidism. Surgical Clinics of North America, 47, 61.

Purnell, D.C., Smith, L.H., Scholz, D.A., Elveback, L.R. \& ARNAUD, E.D. (1971) Primary hyperparathyroidism: A prospective clinical study. American Journal of Medicine, 50,670 .

Raker, J.W., Henneman, P.H. \& Graf, W.S. (1962) Coexisting primary hyperparathyroidism and Cushing's syndrome. Journal of Clinical Endocrinology and Metabolism, 22, 273.

Soloman, N., Carpenter, C.C.J., Bennett, I.L. JR \& HARVEY, A.M. (1965) Schmidt's syndrome (thyroid and adrenal insufficiency) and co-existent diabetes mellitus. Diabetes, 14, 300.

Summerskill, W.H.J., Code, C.F., Hallenbeck, G.A. \& Priestley, J.T. (1961) Intractable peptic ulcer in hereditary endocrine-ulcer disease: gastric content of endocrine tissues. Proceedings. Mayo Clinic, 36, 611. 